\section{Thank You, Santa!}

\author{
Dear Santa,
}

It's Margaret here. Gosh, a lot has happened since I wrote you last year. I do hope that you, Mrs. Claus, and the elves have been safe this year, as I imagine COVID-19 found its way even to the North Pole. But I know you! I believe you would follow every CDC recommendation, even if it is tough to stuff that beard into a face mask. I have to say that you really delivered on my list from 2020! Usually I feel kind of neglected, as if you aren't getting my letters. And I admit I had a very aggressive list—ten wishes! (Although I was just joking about the diamond necklace!)

First, thank you SO much for delivering the effective vaccines that I requested against COVID-19. These may be the most effective vaccines ever manufactured, and trust me, we are all relieved and grateful! But I wish I had also asked for your help in minimizing vaccine hesitancy. Many people have died because low vaccination rates allowed more aggressive variants to emerge. But I believe things are improving now.

You also brought new jobs, encouraged discussions about drug prices, kept the Affordable Care Act from being struck down, and gave us each a mirror to help us see our own biases. That makes 5 of my requests that you delivered on. Unbelievable! Now, I admit that I didn't wake up to all these things on Christmas morning. But I got my first vaccine on Christmas Eve, and I appreciated the promissory notes left in my stocking.

I don't want to seem greedy, but since I scored so well last year, I am going to ask for the other things again. Maybe you are feeling generous? Here is my list:

1. Bring President Biden something magical to heal our country. Things have been pretty rough, though I won't add details because they would dampen my Christmas spirit for sure.

2. Deliver an immunotherapy that works for all cancers. I know this is challenging, but I believe the elves can figure it out.

3. Deliver a bag of patience to everyone. People right now are cranky and tired, and much too cross with each other.

4. When the pandemic is finally over, find a way to keep telehealth as part of medical care. Patients love it.

5. I was going to ask for that diamond necklace again, but no. Maybe that would be pushing my luck.

Well, that's my list. If you want to talk about anything, let's have a meeting over Zoom or Teams. I have now learned how to share my screen, so we can go over things in detail. I'm okay with including the elves if you want, but they must stay on mute or go back to the waiting room. The last time we tried this, I recall them being annoyingly chatty.

Before I close, I want to offer a little recommendation. Please get your booster shot. After all, you are about 2,000 years old and a tad overweight, so your immunity might not be as good as it used to be.

I'll close by wishing you and Mrs. Claus the best of the season. Thanks in advance for all the good cheer and happiness you will pass around this holiday. We all need it, now more than ever.

\section{Sincerely, \\ Marg}

WHAT DO YOU THINK? To submit a Letter to the Editor, email JNCCN@nccn.org or log into www.editorialmanager.com/JNCCN.

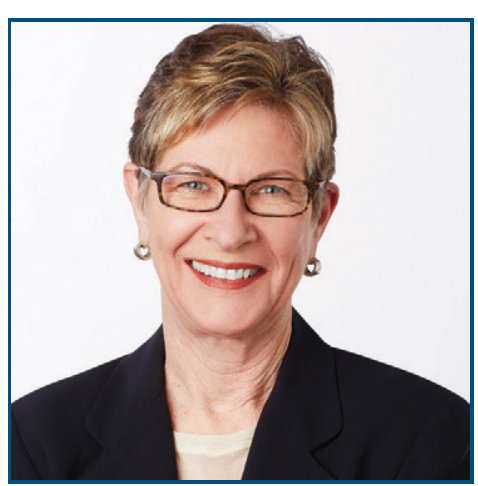

MARGARET TEMPERO, MD

Margaret Tempero, MD, is a Professor of Medicine and Director of the UCSF Pancreas Center and editor-in-chief of JNCCN. Her research career has focused on pancreatic ductal adenocarcinoma, especially in the area of investigational therapeutics. Dr. Tempero has served on the ASCO Board of Directors and as ASCO President. She currently serves on the ASCO Conquer Cancer Foundation Board. She codirected the AACR/ASCO Methods in Clinical Cancer Research and taught this course and similar courses in Europe and Australia. She was founding Chair of the $\mathrm{NCl}$ Clinical Oncology Study Section and served as a member and Chair of the $\mathrm{NCl}$ Board of Scientific Counselors Subcommittee A. She is a member of the Scientific Steering Committee and Chair of the Clinical and Translational Study Section for the Cancer Prevention \& Research Institute of Texas. She is or has been on the Scientific Advisory Boards of the Lustgarten Foundation, the Pancreatic Cancer Action Network, the V Foundation, The Alberta Canada Cancer Board, and the EORTC. She served as a member of the Oncology Drug Advisory Committee for the FDA. She has served as Deputy Director and Interim Director for the UNMC Eppley Cancer Center. She is Chief Emeritus of the Division of Medical Oncology at UCSF. She served as the founding Deputy Director and was later Director of Research Programs at the UCSF Helen Diller Family Comprehensive Cancer Center.

doi: 10.6004/jnccn.2021.0060

The ideas and viewpoints expressed in this editorial are those of the author and do not necessarily represent any policy, position, or program of NCCN 